\title{
Crude Protein and Proline in Dry Bean Seed Respond to Weeding and Soil Fertility Regimes
}

\author{
Silindile P. Miya, Albert T. Modi* \\ Crop Science, School of Agricultural, Earth and Environmental Sciences, University of KwaZulu-Natal, \\ Scottsville, USA \\ Email: *modiat@ukzn.ac.za
}

Received 25 July 2015; accepted 8 November 2015; published 12 November 2015

Copyright (C) 2015 by authors and Scientific Research Publishing Inc.

This work is licensed under the Creative Commons Attribution International License (CC BY). http://creativecommons.org/licenses/by/4.0/

(c) (i) Open Access

\section{Abstract}

The objective of this study was to investigate the effect of weeds and fertilizer application on dry bean seed quality. Four dry bean (Phaseolus vulgaris L.) cultivars, Caledon (C), Ukulinga (U), Gadra (G) and uMtata (M) were planted for seed production using a field experiment designed as a split, replicated three times. There were three levels of weeding W0 (no weeding), W1 (weeding until $50 \%$ flowering) and W2 (weeding all the time until harvest). The weeding treatments were split into no fertilizer application (F0) and optimum fertilizer application (F1) according to soil fertility analysis. At harvest maturity, seeds were compared for quality with respect to size, germination and total protein content. Proline content was determined as a measure of crop response to the weed and fertilizer stresses during crop production. Although seed size was affected by management stress, seed germination was not significantly affected by weeding and fertilizer even when it was explored in terms of seed vigor by determining rate of germination and seedling size. However, weed management and fertilizer application significantly affected proline and total crude protein contents in seeds $(\mathrm{P}<\mathbf{0 . 0 5})$. The findings of this study show that the biotic stress of weeds and abiotic stress of soil fertility can be used to determine seed physiological quality of dry bean seeds.

\section{Keywords}

Abiotic Stress, Biotic Stress, Seed Protein, Proline, Phaseolus Vulgaris

\section{Introduction}

Dry beans (Phaseolus vulgaris L.) are primarily used for worldwide human consumption with an increasing ${ }^{*}$ Corresponding author. 
demand [1]-[3], especially for lower income societies where the crop provides suitable dietary proteins [4]-[6]. The crop is also a rich source of dietary fibre, starch, folate, minerals and vitamins with low amounts of fat and sodium [2]. As is the case for all grain, fodder and vegetable crops, successful dry bean production begins with high quality seed [7]. Seed quality can be influenced by biotic and abiotic environmental conditions during growth and storage before planting. Seed physical and physiological or biochemical qualities are important for seed quality determination. Although seed physiology is an important aspect of seed quality, it is used to a limited extent, mainly in terms of seed viability and germination. Seed viability and germination provide a general indication that the activity of dormancy-breaking enzymes (e.g. alpha-amylase) and phytohormones (e.g. gibberrelic acid) can be confirmed.

Weed management offers more than just eliminating the existing weed population which is the case in weed control. This phenomenon emphasizes weed prevention, reduction of weed emergence after crop planting and minimizing the weed-crop competition [8]. Therefore, weed management is a preventive measure contrary to weed control which is a curative approach. Furthermore, weed management puts great emphasis on the integration of techniques, knowledge and management skills [9]. It has been argued [10] that the phenomenon of weed management depends on varying degrees of crop growth vigor despite the farming practices and environmental diversity where crops are grown. It is crucial to ensure timely weed control before any crop loss, and this should be repeated until late emerging weeds no longer reduce yield [11]. The span time to which crops can tolerate weed interference is very short with variation in pattern of weed growth relative to crops [10]. Preventing yield losses in the field requires the absence of weeds for 5 to 7 weeks after planting [12]. Although there is existing control strategies used to ameliorate weeds problem, there is still a threat in agricultural productivity posed by weeds [13]. Therefore, high level of management is required in dry bean cultivation, more so since the crop is also susceptible to a number of stresses unrelated to weeds [14]. Dry bean yield can be improved several folds with the adoption of appropriate crop management practices [3]. Therefore, implementation of a proper weed management strategy is very important to avoid yield losses [15].

Plant competition and community dynamics are determined and altered by fertilization (nutrient availability) management and timing relative to crop and weed demands upon nutrient supplies [13] [15]. Specific responses of fertilizer application vary depending on the nature of the weed-crop association [16]. However, the interactions between weeds and crops can be influenced by crop fertilization strategy [14]. Therefore, fertility management ensures that crops maximize nutrient uptake and minimize nutrient availability to weeds, thereby reducing weed impact [15]. Moreover, the type of crop and weed species determine the net effect of fertilization on crop yield [17]. Dry matter production of crops increases with an increase in soil fertility unless there is a competition with weeds [18]. Furthermore, the improvement of nutrient uptake by the crop fertilizer application management increases together with its competitiveness for other resources that might otherwise be available for weeds [8] [17].

During initial growth stages, starving weeds may be enhanced by delayed nutrient application, and better matching nutrient supply with crop uptake capacity. However, fertilizer application before or at planting may detrimentally affect the crop through promotion of weed germination whenever weeds absorb nutrients earlier and more rapidly than crops [14]. Under high soil nutrient levels, weeds tend to be more competitive than crops and accumulate more nutrients, resulting in crop loss from weed impact [16] [17]. Evidence of this was shown in a study about the disadvantage of $\mathrm{N}$ fertilizer application which led to increased weed density, thus leading to crop yield decreases [19].

Although research has been reported on the effects of weeds and soil fertility on crop performance from the agronomic perspective, there is a need to explain these factors from the seed quality perspective. The aim of this study was to investigate the possible interaction of weed and soil fertility stress on seed quality. The specific objective was on physical seed quality from the point of view of seed size, seed germination and chemical indicators of crop response to weed and soil fertility stress. The results presented here focus on seed size, chemical composition in terms of a stress indicator, proline, and crude protein content in seeds. No data for seed germination are shown since there are no significant effects of treatments on it at any level.

\section{Materials and Methods}

Four dry bean (Phaseolus vulgaris L.) cultivars, Caledon (C), Ukulinga (U), Gadra (G) and uMtata (M) purchased from Pro-seed were planted for seed production using a field experiment designed as a split, replicated 
three times. U, G and M have a determinate growth habit, whereas, $\mathrm{C}$ is indeterminate. There were three levels of weeding W0 (no weeding), W1 (weeding until 50\% flowering) and W2 (weeding all the time until harvest). The planting density was 100,000 plants ha ${ }^{-1}$. Weeding was done culturally using a hand-hoe and hand-pulling. Fertilizer treatments were split into no fertilizer (F0) and optimum fertilizer application (F1) before planting, using 2:3:2 [20] fertilizer according to soil analysis results (80 kg/ha N, $200 \mathrm{~kg} / \mathrm{ha} \mathrm{P}$ and $60 \mathrm{~kg} / \mathrm{ha} \mathrm{K}$ ). The crop was grown under irrigation using $580 \mathrm{~mm}$ of water over the growing season (13 February-06 June) in 2014 (Figure 1).

At harvest maturity [21], seeds were manually harvested to determined seed quality in terms of 1000 seed mass and seed germination [22]. Protein analysis was conducted according to the Bradford method [20], with some amendments. About $2 \mathrm{~g}$ DW of seed tissue powder was ground with electric blade grinder was used instead of 0.5 g plant. The sample was extracted in $5 \mathrm{ml} 50 \mathrm{mM}$ Tris-HCl buffer (pH 7.4). The Bradford dye (1 ml) was added to test tubes with $20 \mu \mathrm{l}$ sample extract which was mixed and incubated at room temperature for five minutes in $1 \mathrm{ml}$ plastic cuvettes. The samples were read from the spectrophotometer at $595 \mathrm{~nm}$ and the protein concentration was determined through the comparison of results with a standard curve constructed using bovine serum albumin.

Analysis for proline content ( $\mu \mathrm{mol} \cdot \mathrm{g}^{-1} \mathrm{DW}$ ) was conducted according to [23] with the amendment of using seeds as plant material instead of using roots from field grown dry beans. Plant material was homogenized in 10 $\mathrm{ml}(3 \%)$ aqueous sulfosalicylic acid. Filtrate $(2 \mathrm{ml})$, acid ninhydrin $(2 \mathrm{ml})$ and glacial acetic acid $(2 \mathrm{ml})$ were reacted in a test tube for one hour at $100^{\circ} \mathrm{C}$ and thereafter cooled in ice bath. Reaction mixture was extracted with toluene which was thoroughly mixed with a test tube stirrer. Absorbance was read at $520 \mathrm{~nm}$ using toluene as a blank and proline concentration was determined using a standard curve (and calculated as:

$$
\text { Proline }=\frac{[(\mu \mathrm{g} \text { proline } / \mathrm{ml} \times \mathrm{ml} \text { toluene }) \div 115.5 \mu \mathrm{g} / \mu \text { moles }]}{[\mathrm{g} \text { sample } / 5]}
$$

Data from the study were analyzed by using Genstat ${ }^{\circledR}$ version 16 software. When comparing means, standard error of the difference (SED) at a probability level of $5 \%$ was used. Statistical differences were accepted at $\mathrm{P} \leq$ 0.05 .

\section{Results and Discussion}

There were no significant differences between treatments and cultivars with respect to seed germination. Hence, no seed germination data are shown. However, there were significant $(\mathrm{P}<0.001)$ differences between cultivars (Figure 2) and weeding regimes (Figure 3 ) with respect to 1000 grain mass. There were no significant interactions with respect to 1000 grain mass. Although the differences between cultivars can be ascribed to genetic

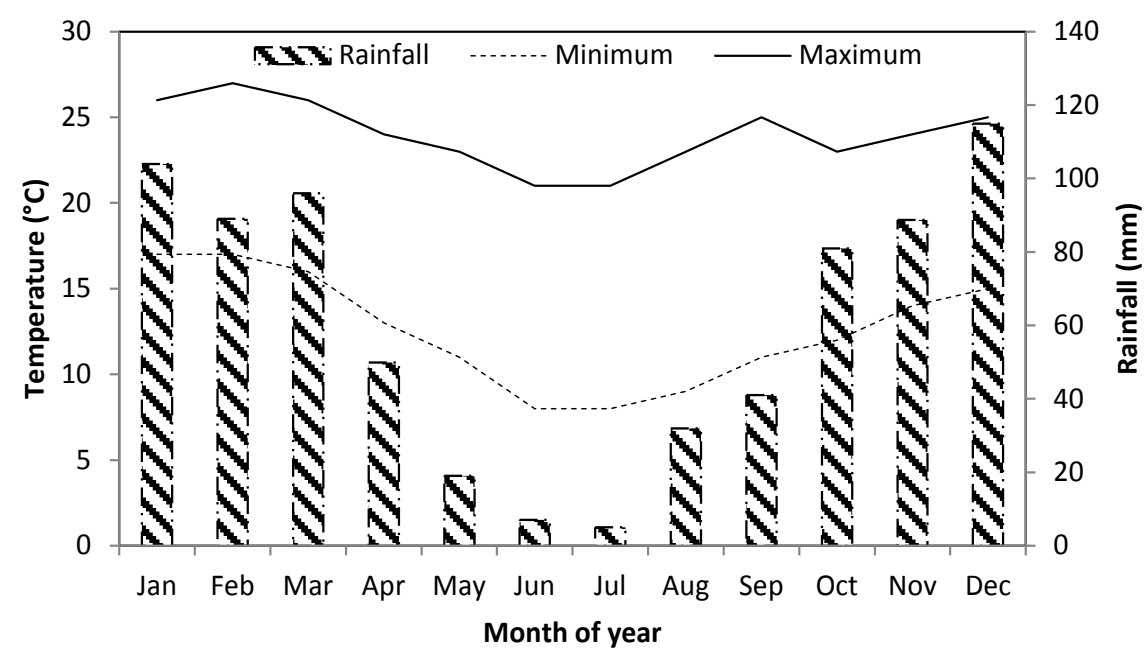

Figure 1. Climatic data for the cropping year (2014), where the crop was grown from February to June. 


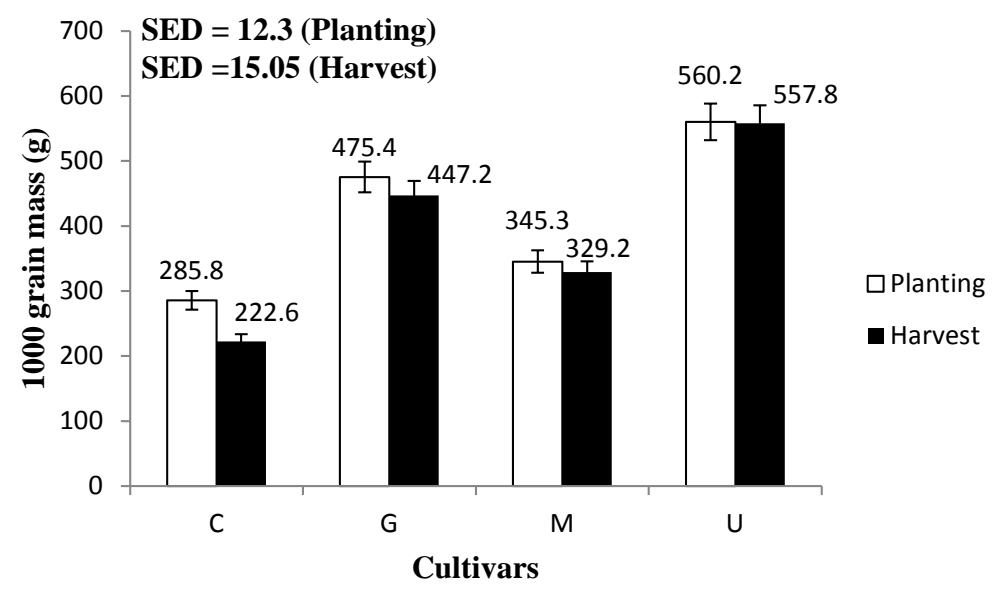

Figure 2. Seed 1000 grain mass at planting and harvest maturity for dry bean cultivars Caledon (C), Ukulinga (U), Gadra (G) and uMtata (M).

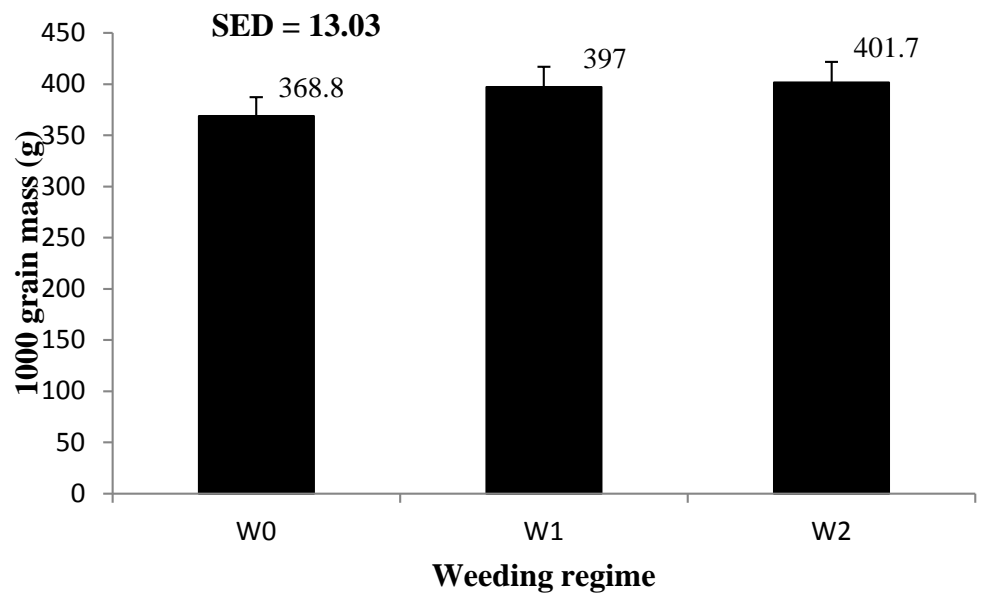

Figure 3. Effect of weeding regime (W0 = no weeding; $\mathrm{W} 1$ = Weeding until $50 \%$ flowering; $\mathrm{W} 2$ = weeding until pod maturation) on dry bean grain mass at harvest maturity.

variation, since there were no significant differences in their harvest maturity seed moisture content of about $15 \%$ (data not shown), it is clear from Figure 1 that cultivar Ukulinga was very resistant to weed stress and Caledon was very sensitive.

There were highly significant $(\mathrm{P}<0.001)$ effects of weeding regime on proline seed content (Figure 4). Weeding treatment W0 led to about 14\% more proline content in seeds compared with W1 and W2 (Figure 3). This is an indication that W0 was most stressful than the other two weeding regimes. There was a minor $(0.6 \%)$, but significant difference between weeding until 50\% flowering and keeping the weeds until crop maturity (Figure 4) with respect to proline content. Fertiliser application significantly $(\mathrm{P}=0.03)$ reduced $(4.3 \%)$ seed proline content compared to no fertiliser application (Figure 5). Fertiliser application also significantly $(\mathrm{P}<0.01)$ increased seed crude protein content (Table 1$)$. The cultivars differed significantly ( $\mathrm{P}=0.02)$ with respect to crude protein content (Table 1).

Although there were no significant differences among weeding regimes, with respect to total crude protein, it is clear from Figure 6 that there was a negative relationship between seed protein and proline contents. According to [24], proline is essential for primary metabolism as a proteinogenic amino acid and is exceptionally conformational rigid [25]. This compound is considered to be a compatible solute and a molecular chaperone that protects folded protein structures from denaturation. It is also considered a protein stabilizer for cell membranes by interacting with phospholipids, enhancing different enzymes activities, functioning as a hydroxyl radical 


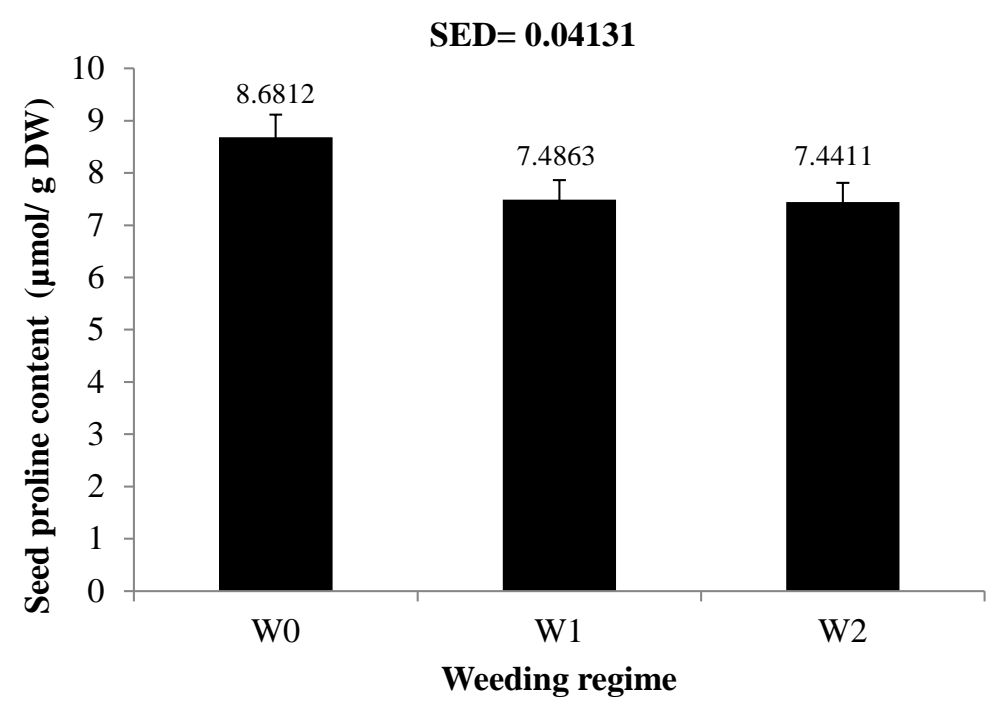

Figure 4. The effect of weeding regime (W0 = no weeding; W1 = Weeding until 50\% flowering; W2 = weeding until pod maturation) on seed proline content.

SED $=0.03$

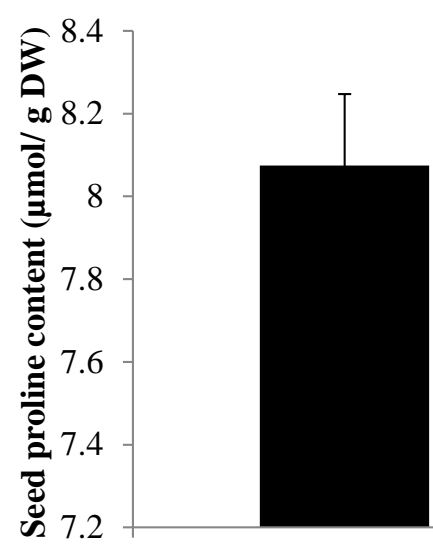

F0
8.0749

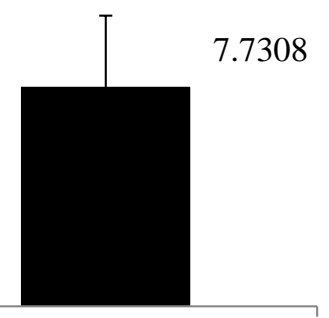

F1

Fertilizer regime

Figure 5. Effect of fertiliser application (F0 = None; F1 optimum) on proline content of mature dry beans.

Table 1. Effect of fertilizer application (F0 = None; F1 optimum) on crude total protein $(\mu \mathrm{g} / \mathrm{gDW})$ of dry bean seeds.

\begin{tabular}{ccc}
\hline Cultivar & Fo & F1 \\
\hline Caledon & $0.028 \mathrm{a}^{*}$ & $0.033 \mathrm{~b}$ \\
Ukulinga & $0.039 \mathrm{c}$ & $0.044 \mathrm{~d}$ \\
uMtata & $0.041 \mathrm{c}$ & $0.053 \mathrm{e}$ \\
Gadra & $0.030 \mathrm{a}$ & $0.038 \mathrm{c}$ \\
Mean & 0.034 & 0.042 \\
SED (Cultivar $\times$ Fertiliser) $=0.002$ & & \\
SED (Fertilizer regime) $=0.003$ & & \\
\hline
\end{tabular}

\footnotetext{
${ }^{*}$ Values sharing the same letters are not significantly different at $(\mathrm{P} \leq 0.05)$.
} 


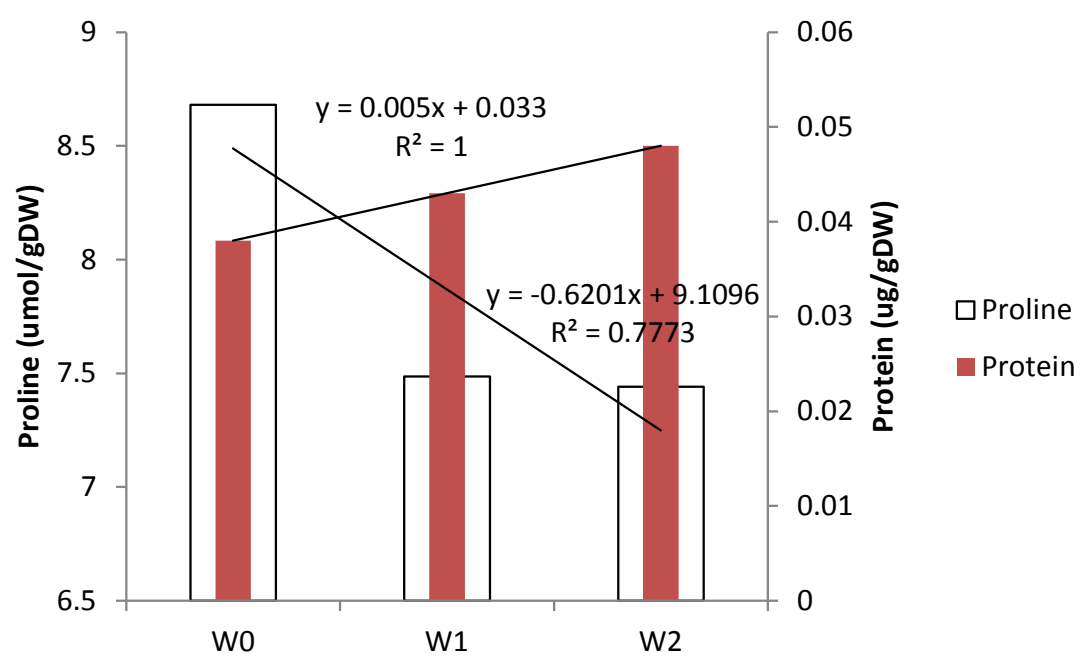

Figure 6. Weeding regime (W0 = no weeding; W1 = Weeding until 50\% flowering; $\mathrm{W} 2$ = weeding until pod maturation) effects, with respect to proline and crude protein contents in dry been seeds across two fertiliser regimes and four cultivars (see Table 1).

scavenger, or serving as an energy and nitrogen source [25] [26]. There have been reports that proline contributes to osmotic adjustment and tolerance of plants exposed to unfavourable environmental conditions [27]. The increase in synthesis of osmoprotectants is a general metabolic adaptation enabling plants to cope with water or osmotic stress, and proline is a well-known osmoprotectant in plants [28] [29]. According to [30] in addition to drought, proline in higher plants tends to increase under different environmental stress conditions such as high salinity, high light and ultraviolet (UV) irradiation, heavy metals, oxidative stress as well as biotic stress [25] [27]. Free proline as an osmoprotectant might eliminate reactive oxygen species (ROS) and promote the antioxidant ability. This compound can also stabilize biological macromolecule structures, decrease cell activity and relieve the toxicity of ammonium $\left(\mathrm{NH}_{4}^{+}\right)$[31]. Chemical changes in response to biotic and abiotic stresses have been observed in other studies [32], although the plant tissue is different.

\section{Conclusion}

Crop nutrition and protection are key aspects of agronomy. In cases where grain crops are produced for seed, these factors become even more important, because their implications go beyond the farm product to the market value for future crop establishment. Seed science studies generally focus on seed quality from the basic physical norms, viability, germination and vigour. This study showed that simply relying on the norms for testing seed quality might lead to the conclusion that some important biotic and abiotic stresses had no effect. This study showed that although seed germination was not affected by weed infestation and suboptimal soil fertility, these factors affected an important aspect of seed quality, 1000 grain mass. As expected, 1000 grain mass was negatively affected by weed infestation and this was countered by optimum fertiliser application. The major finding of this study was showing that the biotic and abiotic stresses caused by weeds and poor soil fertility, respectively, could be linked to physiological indicators of seed quality, seed protein and proline. Given that proline has already been shown to be associated with plant protection against water stress, it would be interesting to use the results of this study to develop a model for testing seed quality in the context of agronomic practices and environmental stress.

\section{References}

[1] Goodwin, M. (2003) Crop Profile for Dry Beans. http://www.pulsecanada.com

[2] Mkanda, A.V., Minnaar, A. and de Kock, H.L. (2007) Relating Consumer Preferences to Sensory and Physicochemical Properties of Dry Beans (Phaseolus vulgaris). Journal of the Science of Food and Agriculture, 87, 2868-2879. http://dx.doi.org/10.1002/jsfa.3046

[3] Singh, S.P., Teran, H., Munoz, C.G., Osorno, J.M., Takegami, J.C. and Thung, M.D. (2003) Low Soil Fertility Toler- 
ance in Landraces and Improved Common Bean Genotypes. Crop Science, 43, 110-119. http://dx.doi.org/10.2135/cropsci2003.0110

[4] Escribano, M.R., Santalla, M. and de Ron, A.M. (1997) Genetic Diversity in Pod and Seed Quality Traits of Common Bean Populations form North-Western Spain. Euphytica, 93, 71-81. http://dx.doi.org/10.1023/A:1002908224793

[5] Broughton, W.J., Hernandez, G., Blair, M., Beebe, S., Gepts, P. and Vanderleyden, J. (2003) Beans (Phaseolus spp.) Model Food Legumes. Plant and Soil, 252, 55-128. http://dx.doi.org/10.1023/A:1024146710611

[6] DAFF (Department of Agriculture, Forestry and Fisheries) (2010) Dry Beans. http://www.nda.agric.za/docs/Brochures/brochuresDryBeans.pdf

[7] Black, M. and Halmer, P. (2006) The Encyclopedia of Seeds: Science, Technology and Uses. CABI, Wallingford.

[8] Buhler, D.D. (2002) Challenges and Opportunities for Integrated Weed Management. Weed Science, 50, 273-280. http://dx.doi.org/10.1614/0043-1745(2002)050[0273:AIAAOF]2.0.CO;2

[9] Mashingaidze, A.B. (2004) Improving Weed Management and Crop Productivity in Maize Systems in Zimbabwe. PhD Dissertation, Wageningen University, Wageningen.

[10] McDonald, G.K. and Gill, G.S. (2009) Improving Crop Competitiveness with Weeds: Adaptations and Trade-Offs. Elsevier Inc., Academic Press, San Diego. http://dx.doi.org/10.1016/b978-0-12-374431-9.00018-9

[11] Donald, W.W. (2000) Alternative Ways to Control Weeds between Rows in Weeded Check Plots in Corn (Zea mays) and Soybean (Glycine max). Weed Technology, 14, 36-44. http://dx.doi.org/10.1614/0890-037X(2000)014[0036:AWTCWB]2.0.CO;2

[12] Wicks, G.A., Johnston, D.N., Nuland, D.S. and Kinbacher, E.J. (1973) Competition between Annual Weeds and Sweet Spanish Onions. Weed Science, 21, 436-439.

[13] Pynenburg, G.M., Sikkema, P.H. and Gillard, C.L. (2011) Agronomic and Economic Assessment of Intensive Pest Management of Dry Bean (Phaseolus vulgaris). Crop Protection, 30, 340-348. http://dx.doi.org/10.1016/j.cropro.2010.12.006

[14] Liebman, M. and Davis, A.S. (2000) Integration of Soil, Crop and Weed Management in Low-External-Input Farming Systems. Weed Research, 40, 27- 47. http://dx.doi.org/10.1046/j.1365-3180.2000.00164.x

[15] Barberi, P. (2002) Weed Management in Organic Agriculture: Are We Addressing the Right Issues? Weed Research, 42, 177-193. http://dx.doi.org/10.1046/j.1365-3180.2002.00277.x

[16] Buhler, D.D. (2004) Weed Biology, Cropping Systems, and Weed Management. Journal of Crop Production, 8, 245270. http://dx.doi.org/10.1300/J144v08n01_10

[17] Michigan State University Extension (2015) Integrated Pest Management. http://www.ipm.msu.edu/agriculture/field_crops/identifying_weeds_in_field_crops

[18] Patterson, D.T. (1995) Effects of Environmental Stress on Weed/Crop Interactions. Weed Science, 43, 483-490.

[19] Rahmati, S., Sajedi, N.A. and Gomarian, M. (2013) Effects of Time Cultivation and Weeds Control Methods on Yield and Yield Components of Red Bean (Phaseolus calcaratus L.). International Journal of Agriculture and Crop Science, 5, 2795-2803.

[20] Bradford, M.M. (1976) A Rapid and Sensitive Method for the Quantitation of Microgram Quantities of Protein Utilizing the Principle of Protein-Dye Binding. Analytical Biochemistry, 72, 248-254. http://dx.doi.org/10.1016/0003-2697(76)90527-3

[21] Sowmya, K.J., Gowda, R., Bhanuprakash, K., Yogeesha, H.S., Puttaraju, T.B. and Channakeshava, B.C. (2013) Enhancement of Seed Quality through Chemopriming in Cucumber (Cucumis sativus L.). Mysore Journal of Agricultural Science, 47, 22-30.

[22] ISTA (2015) International Rules for Seed Testing, Vol. 215, Introduction, i-1-6 (10). The International Seed Testing Association, Bassersdorf.

[23] Bates, L.S., Waldren, R.P. and Teare, I.D. (1973) Short Communication: Rapid Determination of Free Proline for Water-Stress Studies. Plant and Soil, 39, 205-207. http://dx.doi.org/10.1007/BF00018060

[24] Wisiol, K. (1979) Clipping of Water-Stressed Blue Grama Affects Proline Accumulation and Productivity. Journal of Range Management, 32, 194-195. http://dx.doi.org/10.2307/3897121

[25] Szabados, L. and Savoure, A. (2009) Proline: A Multifunctional Amino Acid. Trends in Plant Science, 15, 89-97. http://dx.doi.org/10.1016/j.tplants.2009.11.009

[26] Socias, F.X., Pol, A., Aguiw, F., Vadell, J. and Medrano, H. (1997) Effects of Rapidly and Gradually Induced Water Stress on Plant Response in Subterranean Clover Leaves. Journal of Plant Physiology, 150, 212-219. http://dx.doi.org/10.1016/S0176-1617(97)80205-2

[27] Claussen, W. (2005) Proline as a Measure of Stress in Tomato Plants. Plant Science, 168, 241-248. 
http://dx.doi.org/10.1016/j.plantsci.2004.07.039

[28] Celik, O. and Unsal, S.G. (2013) Expression Analysis of Proline Metabolism-Related Genes in Salt-Tolerant Soybean Mutant Plants. Plant Omics Journal, 6, 364-370.

[29] Xiao, G.J., Zhang, F.J., Qiu, Z.J., Yao, Y.B., Wang, R.Y. and Huang, J. (2013) Response to Climate Change for Potato Water Use Efficiency in Semi-Arid Areas of China. Agricultural Water Management, 127, 119-123. http://dx.doi.org/10.1016/j.agwat.2013.06.004

[30] Cvikrova, M., Gemperlova, L., Martincova, O. and Vankova, R. (2013) Effect of Drought and Combined Drought and Heat Stress on Polyamine Metabolism in Proline-over-Producing Tobacco Plants. Plant Physiology and Biochemistry, 73, 7-15. http://dx.doi.org/10.1016/j.plaphy.2013.08.005

[31] Xiong, J., Zhang, L., Fu, G.F., Yang, Y.J., Zhu, C. and Tao, L.X. (2012) Drought-Induced Proline Accumulation Is Uninvolved with Increased Nitric Oxide, which Alleviates Drought Stress by Decreasing Transpiration in Rice. Journal of Plant Research, 125, 155-164. http://dx.doi.org/10.1007/s10265-011-0417-y

[32] González-Gallegos, E., Laredo-Alcalá, E., Ascacio-Valdés, J., Jasso de Rodríguez, D. and Hernández-Castillo, F.D. (2015) Changes in the Production of Salicylic and Jasmonic Acid in Potato Plants (Solanum tuberosum) as Response to Foliar Application of Biotic and Abiotic Inductors. American Journal of Plant Sciences, 6, 1785-1791. http://dx.doi.org/10.4236/ajps.2015.611179 